\title{
Description of mechanical properties of carbon nanotubes. Tube wall thickness problem. Size effect. Part 2
}

\author{
R.V. Goldstein ${ }^{1}$, V.A. Gorodtsov ${ }^{1, \dagger}$, A.V. Chentsov ${ }^{1}$, S.V. Starikov ${ }^{2}$, \\ V.V. Stegailov', G.E. Norman ${ }^{2}$ \\ †'gorod@ipmnet.ru
}

\author{
${ }^{1}$ A.Yu. Ishlinsky Institute for Problems in Mechanics RAS, prospect Vernadskogo 101-1, 119526 Moscow
}

${ }^{2}$ Joint Institute of High Temperatures RAS, Izhorskaya 13, 125412 Moscow

\section{К описанию механических свойств углеродных нанотрубок. Проблема толщины трубки. Масштабный эффект. Часть 2}

\author{
Гольдштейн Р.В. ${ }^{1}$, Городцов В.А. ${ }^{1}$, Ченцов А.В. ${ }^{1}$, Стариков С.В. ${ }^{2}$, \\ Стегайлов B.B. ${ }^{2}$, Норман Г.Е. ${ }^{2}$ \\ ${ }^{1}$ Институт проблем механики им. А.Ю. Ишлинского РАН, просп. Вернадского 101-1, 119526 Москва \\ ${ }^{2}$ Объединенный институт высоких температур РАН, ул. Ижорская 13, 125412 Москва
}

\begin{abstract}
Эта статья является продолжением Части 1 [1], использующей метод атомного моделирования с потенциалом Терсоффа-Бреннера-Стюарта для описания механических свойств однослойных углеродных нанотрубок. Большой масштабный эффект механических характеристик обнаружен для нанотрубок диаметрами в несколько нанометров. Существенное различие свойств нанотрубок типа “зигзаг” и “кресло” установлено, т.е. спиральность атомной структуры имеет важное значение. Обнаружен эффект разномодульной упругости при растяжении и сжатии нанотрубок. Выявлен масштабный эффект неустойчивости нанотрубок при сжатии.
\end{abstract}

Ключевые слова: углеродные нанотрубки, однослойные углеродные нанотрубки, механические свойства, упругость, масштабный эффект, эффект разномодульности, спиральность, устойчивость нанотрубок

\section{Results and discussion}

In our calculations the SWCNTs [1] were subjected to large tensile and compressive deformations. The typical dependences of calculated force $\mathrm{F}$ on strain $\varepsilon$ are given in Fig. 1. The results for four nanotubes of zigzag type and one nanotube of armchair type are given. The dependences were calculated within the strain range $-0.09<\varepsilon<0.09$ at various radii $r_{0}$ and lengths $l_{0}$ of nanotubes and various temperatures T. Further we shall omit a subscript zero at $l_{0}$ and $r_{0}$ meaning initial equilibrium values of these characteristics. The
This paper is a continuation of Part 1 [1]. Using the method of the atomic modeling based on the Tersoff-Brenner-Stewart potential we describe the mechanical properties of singlewalled carbon nanotubes (SWCNTs). Large scale effect was found for the mechanical properties of nanotubes with diameters of several nanometers. A significant difference in the properties of nanotubes such as "zigzag" and "armchair" is set, i.e., helicity of the atomic structure is essential. The difference in elasticity in tension and compression of nanotubes (bi-modulus effect) is detected. Scaling instability effect of nanotubes in compression is identified.

Keywords: carbon nanotubes, single-walled carbon nanotubes (SWCNTs), mechanical properties, elasticity, size effect, bi-modulus effect, helicity, stability of nanotubes.

discontinuities and sharp bends of curves at compression (at negative values of $\varepsilon$ ) correspond to instabilities which will be discussed below in more detail. The dependences $F(\varepsilon)$ in Fig. 1 are close to a square-law to the right of the instability point,

$$
\mathrm{F}(\varepsilon)=\mathrm{a} \varepsilon-\mathrm{b} \varepsilon^{2} .
$$

Here the coefficients depend on nanotube radius $r$. Temperature has a weak effect as compared to the radius $r$. The $\mathrm{F}(\varepsilon)$ dependence is more influenced by the temperature than by SWCNT length 1 . More detailed information is 
Table 1.

Coefficients for square-law approximation $(1)$ of $\mathrm{F}(\varepsilon)$ at temperature $\mathrm{T}=300 \mathrm{~K}$ (radius $\mathrm{r}$ is given in nanometers).

\begin{tabular}{|c|c|c|}
\hline Type & $\mathrm{a}, \mathrm{nN}$ & $\mathrm{b}, \mathrm{nN}$ \\
\hline $\begin{array}{c}\text { armchair } \\
\text { nanotubes }\end{array}$ & $(1.8 \cdot \mathrm{r}+0.05) \cdot 10^{3}$ & $\begin{array}{c}(11.8 \cdot \sqrt{\mathrm{r}}-5) \cdot 10^{3} \\
(\text { tension})\end{array}$ \\
\cline { 3 - 3 } & & $\begin{array}{c}(20.5 \cdot \sqrt{\mathrm{r}}-8.6) \cdot 10^{3} \\
(\text { compression })\end{array}$ \\
\hline $\begin{array}{c}\text { zigzag } \\
\text { nanotubes }\end{array}$ & $(1.8 \cdot \mathrm{r}+0.2) \cdot 10^{3}$ & $(1.8 \cdot \mathrm{r}+0.2) \cdot 10^{3}$ \\
\cline { 2 - 3 } & & \\
\hline
\end{tabular}

given in Fig. 2 and Fig. 3. The Table I shows the results of calculations of coefficients a and b in an analytic form (1) at temperature $\mathrm{T}=300 \mathrm{~K}$.

The difference in the coefficients for various types of SW$\mathrm{CNTs}$ is essential for nanotubes of small radius r. However, from $\mathrm{r} \approx 4 \mathrm{~nm}$ and larger this difference can be neglected and this is in line with the above discussion.

Note that the coefficient $b$ for armchair nanotubes at compression does not coincide with that at tension (the effect of the Young moduli difference at compression and tension).

The tension force derivative with respect to strain at this nonlinear deformation is not constant. Therefore we introduce variable generalized Young's modulus (surface stiffness) $\mathrm{E}_{\mathrm{s}}$ that depends on deformation (besides the constant generalized surface stiffness $\mathrm{E}_{\mathrm{s} 0}$ (see, Eq.2 [1]))

$$
\mathrm{E}_{\mathrm{s}}=\mathrm{E}_{\mathrm{s}}(\varepsilon)=\frac{1}{2 \pi \mathrm{r}} \frac{\partial \mathrm{F}}{\partial \varepsilon} \approx \mathrm{E}_{\mathrm{s} 0}-\frac{\mathrm{b}}{\pi \mathrm{r}} \varepsilon .
$$

Some simulation results for the dependence $\mathrm{E}_{\mathrm{s}}(\varepsilon)$ are given in Fig. 4 . The results at $\mathrm{T}=10 \mathrm{~K}$ can be analyzed without any ensemble averaging. The results at $\mathrm{T}=300 \mathrm{~K}$ require averaging due to thermal fluctuations. The curves lose some characteristic properties, but general features are remained after averaging. Note that condition (1) is satisfied only after implementation of such procedure. One remarkable feature of the calculated curves is the essential difference

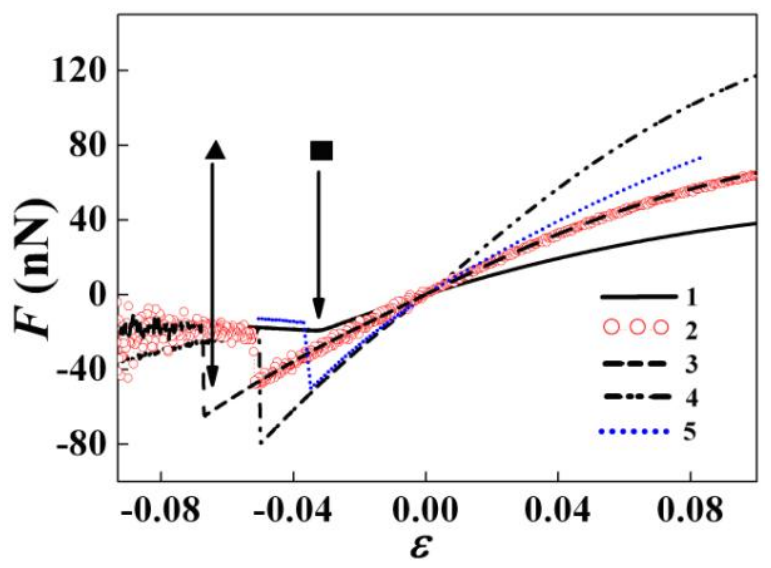

Fig. 1. Dependences of the calculated force $\mathrm{F}$ on deformation $\varepsilon$ for zigzag nanotubes: $1-\mathrm{r}=0.242 \mathrm{~nm}, \mathrm{l}=6.9 \mathrm{~nm}, \mathrm{~T}=10 \mathrm{~K} ; 2-\mathrm{r}=0.392$ $\mathrm{nm}, \mathrm{l}=6.9 \mathrm{~nm}, \mathrm{~T}=300 \mathrm{~K} ; 3-\mathrm{r}=0.392 \mathrm{~nm}, \mathrm{l}=6.9 \mathrm{~nm}, \mathrm{~T}=10 \mathrm{~K} ; 4-$ $\mathrm{r}=0.698 \mathrm{~nm}, \mathrm{l}=6.9 \mathrm{~nm}, \mathrm{~T}=10 \mathrm{~K}$; and for armchair nanotubes: 5 $\mathrm{r}=0.537 \mathrm{~nm}, \mathrm{l}=11.80 \mathrm{~nm}, \mathrm{~T}=10 \mathrm{~K}$. The arrows with triangle and rectangle points are related to the start of axil symmetric buckling and bending instability of nanotubes, respectively.

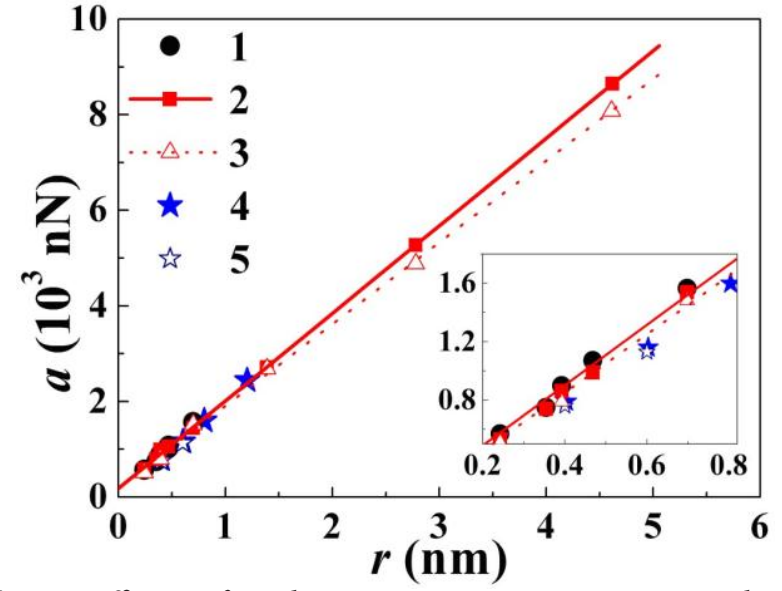

Fig. 2. Coefficient of quadratic approximation a at various radii $r$ of nanotubes: 1 - zigzag type $(\mathrm{T}=10 \mathrm{~K}) ; 2$ - zigzag type $(\mathrm{T}=300 \mathrm{~K})$; 3 - zigzag type (T=700 K); 4 - armchair type $(\mathrm{T}=10 \mathrm{~K}) ; 5$ - armchair type $(\mathrm{T}=300 \mathrm{~K})$.

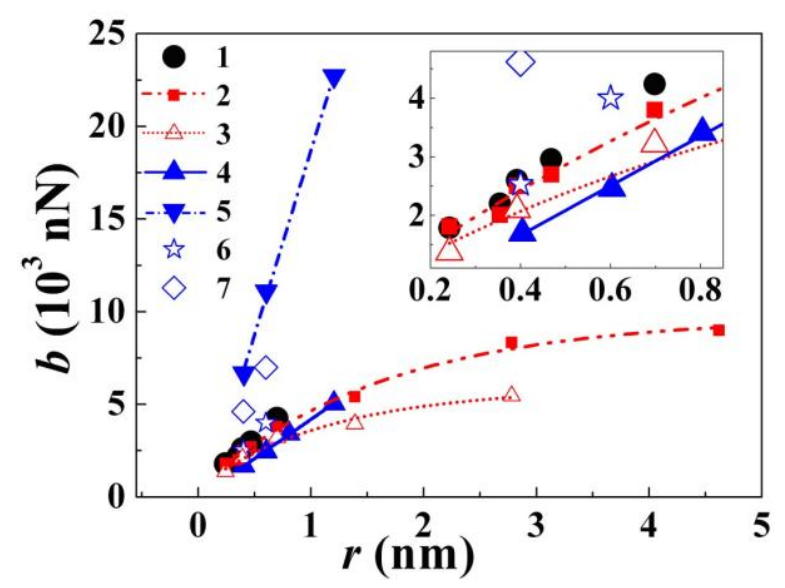

Fig. 3. Coefficient of quadratic approximation $b$ at various radii $r$ of nanotubes: 1 - zigzag type $(\mathrm{T}=10 \mathrm{~K}) ; 2$ - zigzag type $(\mathrm{T}=300 \mathrm{~K})$; 3 - zigzag type $(\mathrm{T}=700 \mathrm{~K}) ; 4$ - armchair type, tension $(\mathrm{T}=10 \mathrm{~K})$; 5 - armchair type, compression $(\mathrm{T}=10 \mathrm{~K}) ; 6$ - armchair type, tension $(\mathrm{T}=300 \mathrm{~K}) ; 7$ - armchair type, compression $(\mathrm{T}=300 \mathrm{~K})$.

between cases of axial tension and compression (after averaging even the data for high temperature deformation of armchair nanotubes). The detailed analysis of mechanical characteristics without averaging is rather difficult even for low temperature at small strain $\varepsilon$.

The generalized Young modulus $\mathrm{E}_{\mathrm{s} 0}$ was calculated as the value of $\mathrm{E}_{\mathrm{s}}(\varepsilon)$ at zero strain. The results of calculation are given in Fig. 5. Even though the performed calculations were not numerous the scale effect for the considered characteristic (i.e. $\mathrm{E}_{\mathrm{s} 0}$ on radius of SWCNT r) is obvious. In the considered range of small radii $r$ the $\mathrm{E}_{\mathrm{s} 0}$ decreases almost by one and $\mathrm{a}$ half times and takes up the constant value at $r \approx 4-5 \mathrm{~nm}$ (i.e. $\left.\mathrm{E}_{\mathrm{s} 0} \approx 0.29 \mathrm{TPa} \cdot \mathrm{nm}\right)$. Note that $\mathrm{E}_{\mathrm{s} 0}$ exhibits a weak tendency to decrease with increase in temperature. The value $\mathrm{E}_{\mathrm{s} 0}$ is also influenced by the type of SWCNT (determined by chirality). The value $\mathrm{E}_{\mathrm{s} 0}$ for zigzag nanotubes exceeds its value for armchair nanotubes. No considerable influence of the nanotube length on the modulus $\mathrm{E}_{\mathrm{s} 0}$ was observed in our study.

As long as the obtained mechanical response was nonlinear the nonlinear behavior of the Poisson's ratio was also studied. This was done for $\varepsilon \neq 0$ and at $\varepsilon \rightarrow 0$, i.e. $v(\varepsilon)$ 


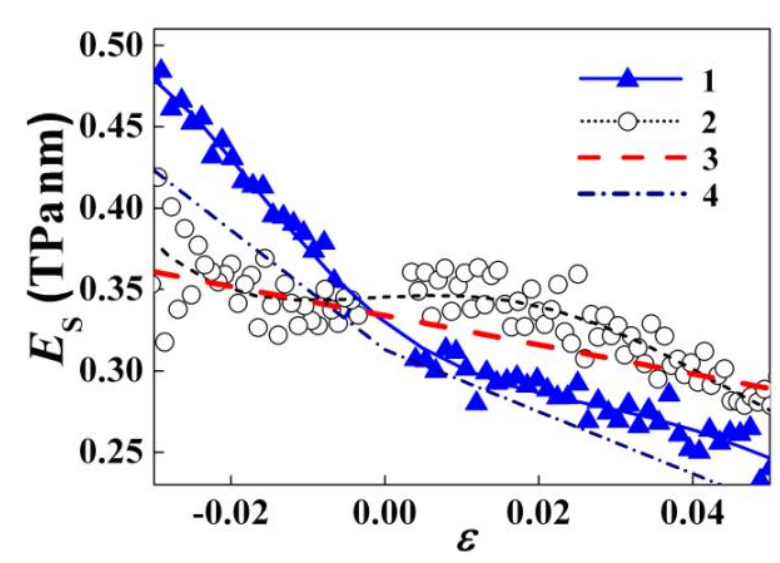

Fig. 4. Dependences of generalized Young's modulus $\mathrm{E}_{\mathrm{s}}$ on deformation $\varepsilon$ : 1 - armchair nanotube with $\mathrm{l}=9.41 \mathrm{~nm}, \mathrm{r}=0.4 \mathrm{~nm}(\mathrm{~T}=$ $10 \mathrm{~K}) ; 2$ - zigzag nanotube with $\mathrm{l}=11.5 \mathrm{~nm}, \mathrm{r}=0.47 \mathrm{~nm}(\mathrm{~T}=10 \mathrm{~K})$; 3 - zigzag nanotube $\mathrm{cl}=11.5 \mathrm{~nm}, \mathrm{r}=0.47 \mathrm{~nm}(\mathrm{~T}=300 \mathrm{~K}) ; 4$ - armchair nanotube with $\mathrm{l}=9.41 \mathrm{~nm}, \mathrm{r}=0.4 \mathrm{~nm}(\mathrm{~T}=300 \mathrm{~K})$.

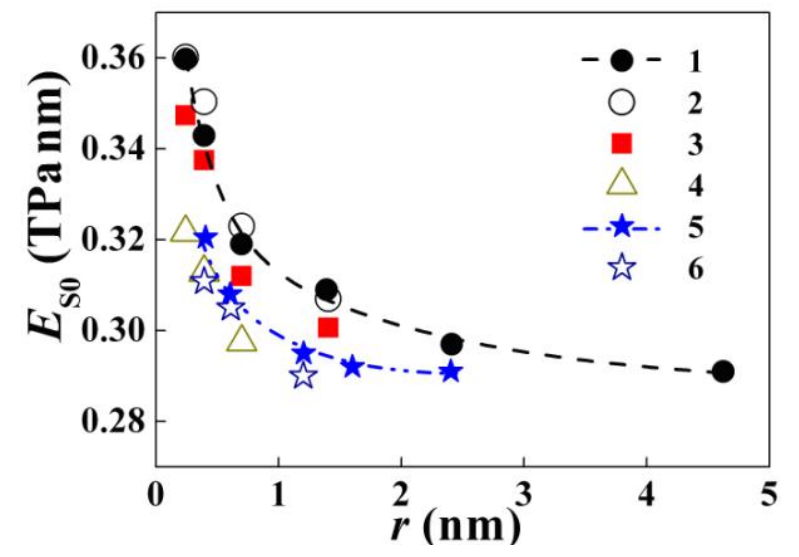

Fig. 5. Dependences of generalized Young's modulus $\mathrm{E}_{\mathrm{s} 0}$ on SWCNT radius $\mathrm{r}$ : $1-\mathrm{l}=18.6 \mathrm{~nm}, \mathrm{~T}=10 \mathrm{~K}$ (zigzag nanotube); $2-\mathrm{l}=6.9 \mathrm{~nm}$, $\mathrm{T}=10 \mathrm{~K}$ (zigzag nanotube); $3-\mathrm{l}=6.9 \mathrm{~nm}, \mathrm{~T}=300 \mathrm{~K}$ (zigzag nanotube); $4-\mathrm{l}=6.9 \mathrm{~nm}, \mathrm{~T}=750 \mathrm{~K}$ (zigzag nanotube); $5-\mathrm{l}=11.8 \mathrm{~nm}, \mathrm{~T}=10 \mathrm{~K}$ (armchair nanotube); $6-\mathrm{l}=11.8 \mathrm{~nm}, \mathrm{~T}=300 \mathrm{~K}$ (armchair nanotube).

and $v_{0} \equiv v(\varepsilon=0)$. The simulation results for Poisson's ratio $v$ vs. strain $\varepsilon$ are given in Fig. 6 . There are three simulations at $\mathrm{T}=10 \mathrm{~K}$ and one at $\mathrm{T}=300 \mathrm{~K}$. The temperature increase did not affect $v(\varepsilon)$ and $v_{0}$ considerably, but noticeably hampered the calculation due to thermal fluctuation, although in general $v(\varepsilon)$ was the same after the averaging. A considerable distinction between $v(\varepsilon)$ for armchair and zigzag nanotubes is observed. There is a sharp maximum of $v(\varepsilon)$ for the armchair nanotubes at $\varepsilon=0$ (it is hard to calculate $v_{0}$ accurately at high temperatures). The dependence of $v(\varepsilon)$ form on the ratio $1 / \mathrm{r}$ (we show below that it is a parameter which adjusts the instability type) was not revealed. Different behavior was observed for zigzag nanotubes. Poisson's ratio remains constant $v \approx 0.3$ at compression and does not depend on deformation for $1 / \mathrm{r}<22$. Ratio $1 / \mathrm{r}$ is a parameter corresponding to the type of loss of stability - either related to the axisymmetric bucling or buckling of an intermediate type. Such Poisson's ratio behavior does not occur at $1 / r>22$. At SWCNTs tension Poisson's ratio $v$ quickly decreases with growth of strain.

The dependence of the Poisson's ratio $v_{0}$ vs. $r$ is given in Fig. 7 at zero strain. It is seen that $v_{0}(r)$ varies for SWCNTs with small radius, but it is practically constant starting from

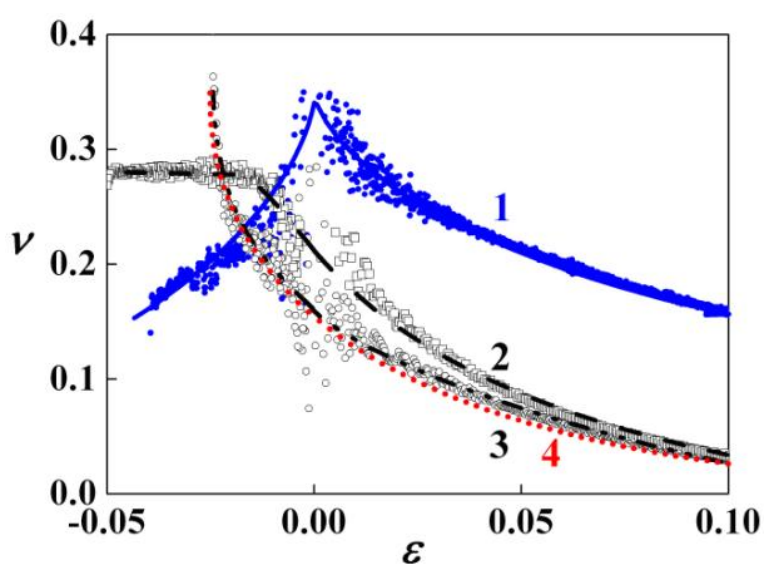

Fig. 6. Dependences of Poisson's ratio $v$ on deformation $\varepsilon$ at temperature $\mathrm{T}=10 \mathrm{~K}: 1-\mathrm{r}=0.603 \mathrm{~nm}, \mathrm{l}=8.2 \mathrm{~nm}$, armchair nanotube; $2-\mathrm{r}=0.698 \mathrm{~nm}, \mathrm{l}=7 \mathrm{~nm}$, zigzag nanotube; $3-\mathrm{r}=0.392 \mathrm{~nm}, \mathrm{l}=1$ $0.3 \mathrm{~nm}$, zigzag nanotube; 4 - results of calculations for $\mathrm{T}=300 \mathrm{~K}$ : $\mathrm{r}=0.392 \mathrm{~nm}, \mathrm{l}=10.3 \mathrm{~nm}$, zigzag nanotube.

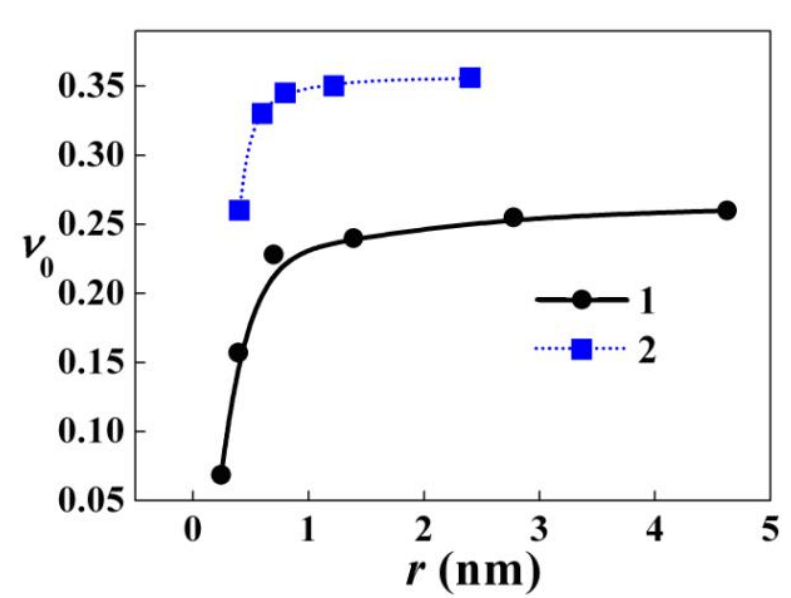

Fig. 7. Dependences of Poisson's ratio $v_{0}$ at zero strain from radius $r$ of zigzag (1) and armchair (2) nanotubes.
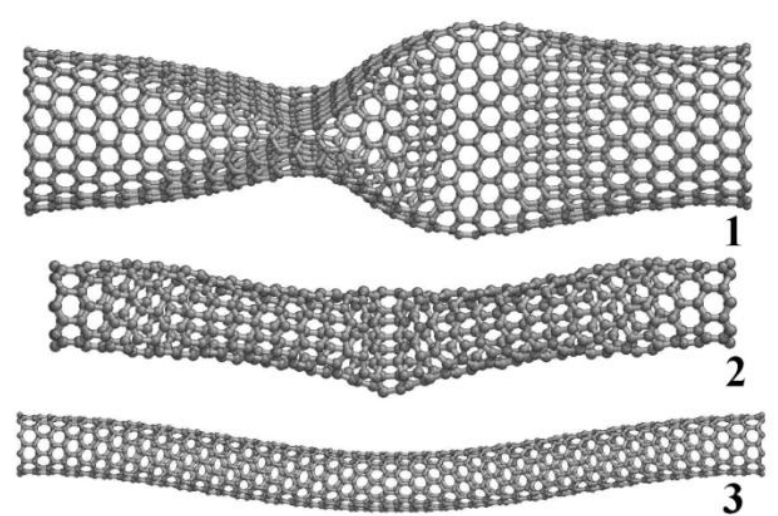

Fig. 8. Types of loss of stability: 1 - axisymmetric buckling $1 / \mathrm{r}<17$; 2 - buckling of an intermediate type, 22>1/r>17; 3 - rod-like bucking, $1 / r>22$.

$\mathrm{r} \approx 4-5 \mathrm{~nm}$. For armchair nanotubes the results are given only for $\mathrm{T}=10 \mathrm{~K}$ (thermal fluctuations and the singularity of curve $v(\varepsilon)$ gives no possibility to study $v_{0}(r)$ at high temperatures). However, for zigzag nanotubes $v_{0}(r)$ does not depend on temperature considerably (that is surely after averaging) and we can expect that the temperature should not influence $v_{0}(r)$ for armchair nanotubes also. What we can say with confidence is that $v_{0}(r)$ depends on SWCNT type. No 


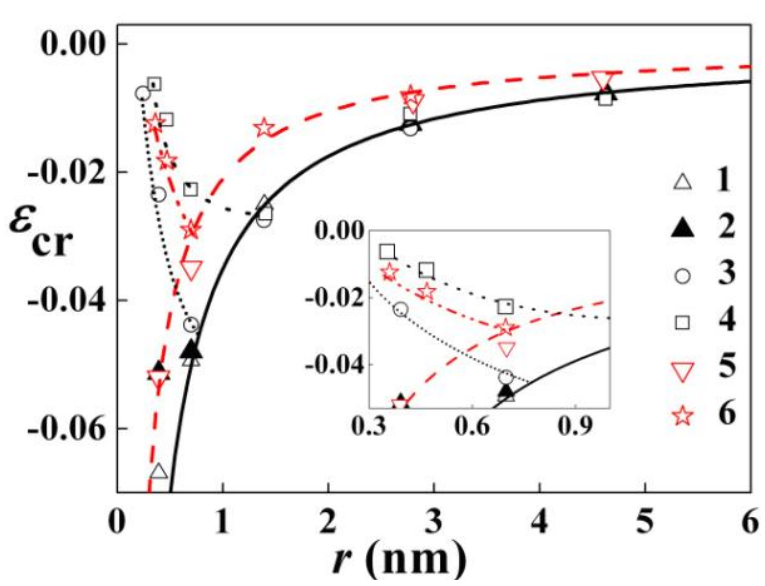

Fig. 9. Critical deformation at compression $\varepsilon_{\mathrm{cr}}$ vs. radius of zigzag nanotubes $\mathrm{r}$ : $1-\mathrm{l}=6.9 \mathrm{~nm}(\mathrm{~T}=10 \mathrm{~K}) ; 2-\mathrm{l}=8.2 \mathrm{~nm}(\mathrm{~T}=10 \mathrm{~K}) ; 3-$ $\mathrm{l}=10.7 \mathrm{~nm}(\mathrm{~T}=10 \mathrm{~K})($ at $\mathrm{l} / \mathrm{r}>21$ the data is marked by "short dots"); $4-\mathrm{l}=18.6 \mathrm{~nm}(\mathrm{~T}=10 \mathrm{~K})($ at $\mathrm{l} / \mathrm{r}>21$ the data is marked by "dots"); $5-\mathrm{l}=6.9 \mathrm{~nm}(\mathrm{~T}=300 \mathrm{~K}) ; 6-\mathrm{l}=16.6 \mathrm{~nm}(\mathrm{~T}=300 \mathrm{~K})($ at $\mathrm{l} / \mathrm{r}>21$ the data is marked by "dash dot dot"). For the deformation at $1 / \mathrm{r}<17$ all the data are combined into a single curve independent on length l, but depending on temperature. The solid curve corresponds to $\mathrm{T}=10 \mathrm{~K}$ and the dashed curve is for $\mathrm{T}=300 \mathrm{~K}$.

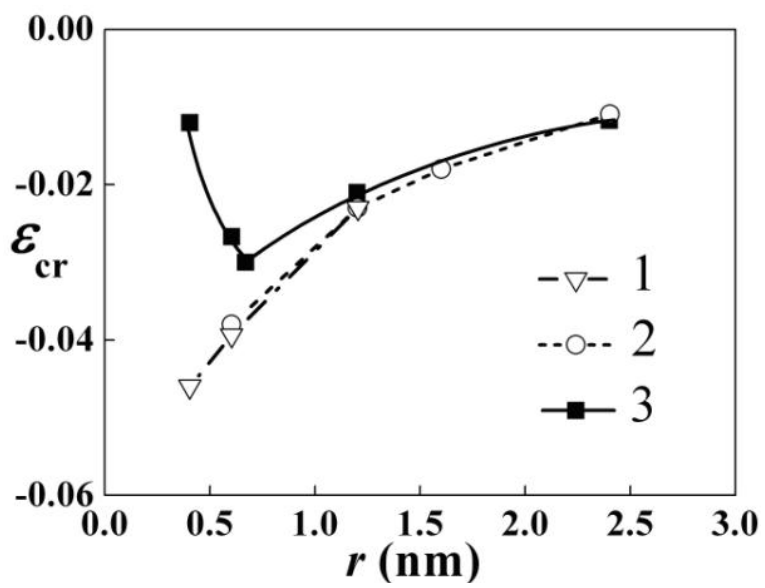

Fig. 10. Critical deformation at compression $\varepsilon$ vs nanotube radius $\mathrm{r}$ for different armchair nanotubes: $1-1=8.2 \mathrm{~nm}, 2-1=11.8 \mathrm{~nm}$, $3-\mathrm{l}=16.2 \mathrm{~nm}$.

variation of $v_{0}$ on SWCNT length 1 was observed. Note that there is a similar scale effect for the Poisson's ratio $v_{0}$ and $\mathrm{E}_{\mathrm{s} 0}$ though their change is inverse (e.g. Fig.5 and Fig.7).

Three basic types of loss of stability have been revealed in numerical modeling of SWCNT axial compression. These three forms of loss of stability are given in Fig. 8. Realization of these forms is defined by SWCNT geometric characteristics. The axisymmetric buckling type of axial loss of stability was observed for $1 / r<17$ that corresponds to break of $F(\varepsilon)$ in Fig.1. The rod-like buckling occurs at $1 / r>22$. There is a sharp bend of $\mathrm{F}(\varepsilon)$ curve in such case. If the intermediate condition $22>1 / r>17$ is fulfilled for the SWCNT geometry then it shows buckling of the intermediate type (also with a break on $\mathrm{F}(\varepsilon)$ curve in Fig. 1). The dependence of buckling critical strain $\varepsilon_{\mathrm{cr}}$ at axial compression on geometric parameters of SWCNT is quite complicated. The results of simulations of the dependence for zigzag and armchair nanotubes are given in Fig. 9 and Fig.10. The nonmonotone character of $\varepsilon_{\mathrm{cr}}(\mathrm{r})$ is due to the variety of the loss of stability types described above.

\section{Conclusions}

It has been shown that the classic elasticity theory cannot be applied to SWCNTs and to thin-walled MWCNTs. The molecular dynamics simulation of uniaxial tension (compression) of SWCNTs was performed using the Tersoff-Brenner-Stuart potential. The nanotubes mechanical characteristics (generalized Young's modulus and Poisson's ratio) were obtained without using concepts of the classical elasticity theory. Our simulations establish a link between these generalized characteristics, value of deformation and nanotubes diameters. It was shown that the scale effect vanishes for nanotubes of large diameters. The dependence of the generalized modulus $\mathrm{E}_{\mathrm{s}}$ on axial tensile deformation is linear.

This modulus (and Poisson's ratio) is also affected by the nanotube chirality. Different moduli in tension and compression were found for armchair nanotubes ("bimodulus effect"). Three types of SWCNTs loss of stability at axial compression were identified.

Thus, using the generalized mechanical characteristics that are calculated using the energetic approach along with the geometric and structural parameters, one can describe the mechanical response of carbon nanotubes at the atomic scale. The generalized characteristics in the case of thickwalled MWCNTs will tend to macroscopic characteristics of elasticity as the considered scales are increased over the atomic scale.

The molecular dynamics modeling procedure using the Tersoff-Brenner-Stuart potential that was used in the present study is initially suitable for hydrocarbons modeling so a further development of the performed analysis is possible for the case of CNT-polymer composites considering various temperatures and regimes.

V.A. Gorodtsov thanks Dr. D.S. Lisovenko for the help in preparing this article.

\section{References}

1. R.V. Goldstein, V.A. Gorodtsov, A.V. Chentsov, S.V. Starikov, V.V. Stegailov, G.E. Norman. Letters on materials 1(4), 185 (2012) (in Russian) [Гольдштейн P.В., Городцов В.А., Ченцов А.В., Стариков В.В., Стегайлов В.В., Норман Г.Е. Письма о материалах 1(4), 185 (2012)]. 